\title{
ART Acceptability in Children: A Randomized Clinical Trial
}

\section{Aceitabilidade da ART em crianças: um ensaio clínico randomizado}

Patrícia Blaya Luz ${ }^{1}$, Juliana Sarmento Barata ${ }^{2}$, Cecília Romero Meller ${ }^{3}$, Sonia Maria Blauth de Slavutsky ${ }^{4}$ Fernando Borba de Araujo ${ }^{5}$

\section{Resumo}

Objetivo: comparar a aceitabilidade da ART e de restaurações convencionais em crianças. Material e métodos: A amostra do presente ensaio clínico randomizado foi composta por 30 crianças de 4 a 7 aanos de idade que tinham pelo menos uma cavidade ativa classe II em um primeiro molar que era acessível a instrumentos manuais. Os grupos de tratamento foram: grupo controle - tratamento com anestesia local, isolamento absoluto, instrumentos rotatórios e resina composta; grupo teste - tratamento de acordo com ART utilizando instrumentos manuais somente, sem anestesia e ionômero de vidro. Em ambos os grupos, somente tecido cariado desmineralizado e esmalte sem suporte foram removidos. A aceitabilidade dos dois grupos foi acessada por mensuração das sensações emocionais usando a Escala de Imagem Facial (EIF) antes e depois do procedimento. Resultados: Não houve diferenças significativas entre os grupos na mudanças dos escores da EIF. $50 \%$ das crianças do grupo teste ficaram mais satisfeitas, enquanto $64 \%$ das crianças do controle não mudaram seus sentimentos. Conclusão: ART não demonstrou ter melhor aceitabilidade do que o tratamento convencional. Entretanto, o menor tempo utilizado para completar o procedimento parece ser um aspecto válido em crianças muito jovens ou pacientes com problemas de comportamento.

Palavras chave: ART, cárie dentária, classe II, dente decíduos

\section{Abstract}

Aim: to compare the acceptability of the ART and the conventional restoration approaches in children. Material and methods: The sample of the current randomized clinical trial was 30 children 4 to 7 years old who had at least one class II active cavity in a primary molar that was accessible to hand instruments. The treatment groups were: Control Group- treatment with local anesthesia, rubber dam, rotary instruments and composite resin. Test Group- treatment according to ART approach using only hand instruments, no anesthesia and glass ionomer. In both groups, only the demineralized carious tissue and unsupported enamel were removed. The acceptability of the two groups was assessed by measuring the emotional feelings represented by Face Image Scale (FIS) before and after the procedure. Results: There was no significant difference between the two groups regarding changes in FIS scores. Fifty percent of the children from the Test Group got more satisfied after the procedure, while $64 \%$ of the participants from Control Group did not change their feelings. Conclusion: The ART approach had not demonstrated to have a best acceptability then the conventional approach. However the short time taken to complete the procedure seems to be worthy aspects when dealing with very young children or patients with behaviors problems.

Keywords: ART, dental caries, class II, primary teeth.

\author{
${ }^{1}$ Aluna de Doutorado em Clínicas Odontológicas com Enfâse em Odontopediatria na \\ Universidade Federal do Rio Grande do Sul \\ ${ }^{2}$ Doutora em Cariologia \\ ${ }^{3}$ DDS \\ ${ }^{4}$ Professora Associada de Saúde Bucal Coletiva da Universidade Federal do Rio \\ Grande do Sul \\ ${ }^{5}$ Professor Associado de Odontopediatria da Universidade Federal do Rio Grande do \\ Sul
}

Correspondência: Patrícia Blaya Luz

Endereço: Rua Dona Laura 414, compl. 406

Fone: (51) 33337100

Email: patriciablayaluz@gmail.com

Data de Submissão: 03/07/2012

Data de Aceite: $13 / 08 / 2012$

\section{Introduction}

The atraumatic restorative treatment (ART) was developed in the 1980s originally for application in underserved communities (VAN AMERONGEN ; RAHIMTOOLA 1999; VAN 'T HOF, 2006). The ART approach consists in a minimal intervention technique based on removing carious tooth tissue using hand instruments and restoring the cleaned cavity with an adhesive material, currently glass ionomer (SCHRIKS; VAN AMERONGEN, 2003). However, because the technical facilities, the advance in etiopathogeny of caries and the lower cost of this new approach, ART has been very usefulness in dental practice in developed countries as well (VAN 'T HOF, 2006).

The word "atraumatic" in the name of the technique means that the treatment causes no or minimal trauma to the patient, in terms of pain, and to the decayed tooth, regarding conservation of sound dentine and pulp tissue; or that any trauma experienced is less than in other invasive technique (VAN AMERONGEN; RAHIMTOOLA, 1999). Unlike conventional cavity preparations, where sound dentine is inevitably removed either intentionally or unintentionally, the use of hand instruments limits the removal to the outer carious dentine only and therefore seams to be insensitive (FRENCKEN; MAKONI; SITHOLE, 1998). Hence, local anesthesia is rarely necessary, which make this approach even more atraumatic (HOLMGREN; FRENCKEN, 1999).

Usually when young patients required an invasive approach is interesting to reduce the discomfort in order to give a pleasant dental experience to the child. The ART has been compared to traditional approaches using rotary instruments in the treatment of carious primary teeth in terms of psychological aspects (VAN AMERONGEN; RAHIMTOOLA, 1999; LO et al., 2001; SCHRIKS; VAN AMERONGEN, 2003; VAN BOCHOVE; VAN AMERONGEN, 2006; MICKENAUTSCH; FRENCKEN; VANIT, 2007; TOPALOGLUAK; EDEN; FRENCKEN, 2007). In contrast, there is no data, al least of our knowledge, that compares the acceptability of ART and conventional approach in young children.

The aim of the present study was to compare the child's acceptability of the ART and the conventional approaches in the 
treatment of class II caries lesions. In this study, the term acceptability reaches subjective aspects, such as pain, discomfort, anxiety and fear. The nulls hypothesis tested were: (1) there is no difference in terms of acceptability of the ART and conventional approach; (2) there is no relation between the acceptability and the success rate of the restorations in both treatments groups.

\section{Material and methods}

The sample of the current randomized clinical trial was 30 children (16 girls), 4-7 years old, who have looked for dental treatment at Dentistry School of the Federal University of Rio Grande do Sul. Inclusion criteria was defined as: each child needed to have at least one approximal active caries lesion in a primary molar that was accessible to hand instruments as prescribed for ART approach (SCHRIKS; VAN AMERONGEN, 2003). All teeth included in the study were radiographed and showed that the caries lesion was in deeper half of dentine and that no pulp involvement was presented. Children who have spontaneous pain were excluded. A signed parental consent form was received from each participant prior to the study's commencement. This research project was approved by the Ethic Committee of the Dentistry School of the Federal University of Rio Grande do Sul.

The study compared two treatment groups. Children in Control Group were treated with local anesthesia, rubber dam, rotary instruments and the cavity was filled with composite resin ( Z 350 3-M ESPE, St. Paul, Minnesota). Children in the Test Group were treated according to ART approach using only hand instruments, no anesthesia and restorative material was glass ionomer ( Ketak-Molar 3-M ESPE, St. Paul, Minnesota). In both groups, only the demineralized carious tissue and unsupported enamel were removed. Matrix band and wooden wedges were also used in both groups. Patients were randomly assigned to one of the treatment group after stratification for tooth in the upper/lower jaw using a ballot box. One trained operator carried out all the treatments helped by a chair-side assistant who recorded the time taken to complete the procedure, starting from local anesthesia and relative isolation in Control and Test Group, respectively, to the time when the child could leave.

The acceptability of the two groups was assessed by measuring the emotional feelings represented by Face Image Scale (FIS) before ( FIS 1) and after (FIS 2) the procedure (BUCHANAN; NIVEN, 2002). One trained interviewer who was blind regarding the experimental group, asked the children: -"How are you feeling now?" and explained the five faces from de very unhappy to the very happy one. Besides that, by the end of the procedure the interviewer asked if the child felt any pain or discomfort during the treatment and if she/he was willing to received the same treatment again (LO; HOLMGREN, 2001). All the interviews were performed in the dental setting with the parents, who were asked to let the children answered by themselves. The operator was absent.

After six months, the restoration performance was assessed using USPHS modified criteria (RYGE, 1980). The parameters evaluated were marginal integrity, anatomical form, surface texture and loss of the material. A calibrated examiner conducted the clinical assessment. The mean kappa values across the four different aspects obtained for Test Group restorations was 0.81 and for Control Group 0.90. A unified success rate criterion was computed for each individual if a $\mathrm{C}$ score was observed for any one of the four USPHS characteristics. The score $C$ represented a failure in which the restoration needs to be replaced.

\section{Statistical Analyses}

FIS scores were considered the primary outcome of the present study. Comparisons between the two groups before and after the operative procedure were performed using the Mann-Whitney $U$ test. The difference in FIS scores before and after the procedure were calculated and compared between groups. Changes in FIS scores within each group were analyzed by the Wilcoxon paired-samples test. Stratified analyses were conducted to evaluate the effect of age, gender, and previous dental experience on the primary outcome. Additionally, linear regression analyses were performed to evaluate the effect of age, gender and previous dental experience on changes in FIS scores between groups.

Moreover, pain during the procedure and the willing to receive the same treatment again were considered secondary outcomes. Comparisons between groups were performed using the Chi-square test.

The success rate was compared between two experimental groups after 6 months using the Fisher's exact test.

Percentage distribution of scores before and after the operative procedures was presented. The individual was considered the unit of analysis. The significance level was set at $5 \%$.

\section{Results}

Only one child, from the Test Group could not receive the treatment because of behavior problems. All 30 children (16 females and 14 males) answered the interviewer's questions. The two experimental groups did not differ in age or gender. Control Group was formed by sixteen children and Test Group by fourteen. After 6 months only 23 children were evaluated (Control Group $n=12$; Test Group $n=11$ ). Two children, one from Control and one from Test Group have moved to another province. Two children from Control group were absent. One child from Control Group and two from Test Group have had their restoration replaced and were classified into restoration failure. One of them was the child who did not let the operator complete the restorative procedure.

The mean time taken to provide the restorations in Test Group was 16'19" (SD 3'5") while for Control Group was 37'64" (SD 9'6"). This difference was significant $(p<0.001)$.

Irregular distributions of FIS score were observed. No child, from both groups, before or after the procedure, was feeling unhappy (Face 4). Besides that, in Control Group, for FIS 1 no child was feeling either very unhappy (Face 5).

There was no significant difference between the two groups regarding changes in FIS scores. Although, there was a trend that Test Group may felt less discomfort. Fifty percent of the children from this group got more satisfied after the procedure, while $64 \%$ of the participants from Control Group did not change their feelings. This difference demonstrated a borderline $p$ value (Table 1). Stratified analyses according to age, gender and previous dental experience demonstrated no significant differences between groups. Moreover, no statistically significant effects of age, gender and previous dental experience were observed in the linear regression analysis. Nevertheless, a borderline negative association was observed between age and FIS 2 regardless of the treatment groups $(b=-0.4$, $p=0.07$ ), indicating that there was a trend for older children to be more satisfied after the operative procedure then the younger ones (data not shown). 
Table 1. Number of children (percentage) demonstrating changes on FIS scores in the two groups. (-1=satisfied; $0=$ no change; $+1=$ unsatisfied)

\begin{tabular}{lll}
\hline & \multicolumn{2}{l}{ Treatment Group } \\
\cline { 2 - 3 } Fis Difference & \multicolumn{1}{c}{ Test } & \multicolumn{1}{c}{ Control } \\
\hline-1 & $8(50.0 \%)$ & $2(14.3 \%)$ \\
0 & $4(25.0 \%)$ & $9(64.3 \%)$ \\
1 & $4(25.0 \%)$ & $3(21.4 \%)$
\end{tabular}

Chi-square $p$ value $=0.062$

No statistically difference was found in the analyses of the questionnaire (direct questions about the pain during the procedure and the willing to receive the same treatment again). Stratified analyses according to age, gender and previous dental experience demonstrated no significant differences between groups. The results are shown in Table 2 and Table 3.

Table 2. Percentage of children's answers for "Did you feel any pain or discomfort during the treatment?"

$$
\text { Treatment Group }
$$

\begin{tabular}{lll}
\cline { 2 - 3 } Pain & \multicolumn{1}{c}{ Test } & Control \\
\hline No & $6(37.5 \%)$ & $8(57.1 \%)$ \\
Yes & $10(62.5 \%)$ & $6(42.9 \%)$ \\
\hline
\end{tabular}

$p=0.282$

Table 3. Percentage of children's answers for "Would you be prepared to receive the same type of treatment again?"

Treatment Group

\begin{tabular}{lll} 
Willing to receive the same & \multicolumn{1}{c}{ Test } & Control \\
\cline { 2 - 3 } treatment again & $10(62.5 \%)$ & $4(28.6 \%)$ \\
\hline No & $6(37.5 \%)$ & $10(71.4 \%)$ \\
Yes &
\end{tabular}

$p=0.63$

Test Group has shown $23 \%$ of success rate and Control Group $75 \%$. This difference was statistically significant $(p=0.03)$. When the results of FIS 2 and FIS Difference were compared to results of restorations performance, no relation was found.

\section{Discussion}

FIS is a picture scale validated for children that measures their anxiety state and should be administered before treatment begins (BUCHANAN; NIVEN, 2002). Because the purpose of the present study was to know the acceptability of two different restorative techniques, the FIS was performed before and after the procedures. It is known that evaluating the anxiety before providing the restorative treatment is very important (SCHRIKS; VAN AMERONGEN, 2003). Even knowing that FIS measures the anxiety and not acceptability we understood that this feeling is most likely related to the acceptability then fear or pain. Thus, FIS was the instrument chosen because of three following reasons: it is quick and easy to administer; it can be employed with very young children; it has been showed to have a strong correlation with the Venham Score (BUCHANAN; NIVEN, 2002). The Venham evaluation was originally assessed using a combination of four measurements: heart rate, ratings of clinical anxiety, ratings of cooperative behavior and the Venham Picture Test (VENHAM; BENGSTON; CIPES, 1977). Moreover, Shirks and Van Amargeroden (2003) demonstrated a correlation between Venham Picture Test and heart rate. Several studies use only the Venham Picture Test to assess children's dental anxiety. It consist of 8 pictures representing feelings ranging from anxiety to contentment, and child must choose which is most similar to her/his feelings at that moment (TOPALOGLU-AK; EDEN; FRENCKEN, 2007).

The results of the present study showed that there was no significant difference between two groups even after comparison with all variables (FIS Difference, FIS scores, questionnaire with direct questions, gender, age and dental previous experience). This may have happened duo to limitations of the study, mainly the reduced sample size. Moreover, the results might not be properly compared, because the two groups were not homogeneous in the begging (no child in FIS 1 from the Control Group was feeling unhappy or very unhappy, Face 1 and Face 2). Additionally, in spite of FIS validation for young children, we found difficulty to assess their anxiety by using this scale. Very often the youngest participants could not link the FIS with the dental treatment. Thus, care should be taken when extrapolating the results of this study.

Topaloglu-Ak, Eden and Frencken (2007) found similar results in their study. They evaluated the anxiety of 6-7 years-old children after a conventional restorative treatment (with bur) and ART in class II of primary molars. Venham Picture Test was used to assess anxiety and no significant difference regarding treatments groups was found. All participants have never visited a dentist before. These authors also understood that using a picture scale to assess anxiety is easy, practical because overcome verbal-cognitive difficulties in young children. Although, they discussed the capacity of this instrument to link the feelings from the moment the child is receiving the procedure to when he/she is answering the scale. They observed that sometimes children were crying during the restorative treatment and after, when they were already relaxed, they chose a non anxious picture.

A 2001 study in China (LO; HOLMGREN, 2001) provided restoration using the ART approach to a pre-school children ( mean age 5.1 SD 0.7years) in a kindergarten environment. After the provision of the treatment, the operator classified the behavior of the child into: co-operative, slightly uncooperative and very uncooperative. When the child returned to the classroom after the treatment, the child's teacher asked if there had been any pain or discomfort during the treatment and whether the child would be prepared to receive the same type of treatment again. In a total of 96 children, only one child was so uncooperative that the treatment could not be placed and $4 \%$ was slightly uncooperative. The majority of the subjects $(93 \%)$ told the teacher that they did not feel any pain and $86 \%$ were willing to receive ART again. They found that the vast majority of the young children considered ART very acceptable. The authors discussed that this was probably because the treatment was provided in the familiar setting of kindergarten. Besides that, the use of ART eliminated the need for local anesthesia and the noisy of the water spray commonly associated to cavity preparation. It is complicated to understand the differences between this study and the present one. The environment aspect is probably very important but maybe if they had a control group theirs results could be similar to the present study. TopalogluAk, Eden and Frencken (2007) found opposite results in terms of location ( children felt less anxiety at the dental clinic than at school). The plausibility of the location as factor that interferes in the anxiety is still unknown.

In a 2003 study, ART was compared to treatment using rotary instruments (750r.p.m) in class II restoration in 403 children mean age 6.3year (SCHRIKS; VAN AMERONGEN, 2003). Glass 
ionomer cement was used in both groups. Discomfort level was determined using heart rate and behavior observation according to Venham score. Children from the ART group experienced less discomfort then those from the rotary instruments group. It is important to stretch that this behavior score was assessed by the dentist and not by the child.

Another study from van Bochove and van Amerongen (2006) who compared 4 experimental groups (ART with and without local anesthesia and conventional approach with and without local anesthesia) demonstrated using Venham Score that ART without local anesthesia gave the most comfort and conventional treatment with local anesthesia resulted in the most discomfort. It also interesting to emphasis that the Venham's ratings of clinical anxiety was assed, by a dentist, on 7 fixed moments (during the entrance in the treatment room; during local anesthesia; at the start of preparation; during deep excavation; during application of the matrix and wedge; at the start of glass ionomer restoration and at the end of restoration). Not surprisingly, during application of matrix band and wedge the rating for comfort between the 4 groups were significant different, in witch ART with local anesthesia was the most comfort one, followed by conventional approach with local anesthesia, ART without anesthesia and conventional without anesthesia.

In agreement, the operator from the present study realized that the majority of children from the Test Group felt pain and started to cry during the application of matrix and wedge. This did not happen with the subjects from the Control Group.

Earlier studies found significant difference between gender and dental fear, showing that girls are most likely to be anxious then boys (SCHRIKS; VAN AMERONGEN, 2003; VAN BOCHOVE; VAN AMERONGEN, 2006). In spite of the reduced sample size, the present study could not find this difference. The previous study in which the children assessed their anxiety is in accordance to our study regarding no difference between genders or treatments groups (TOPALOGLU-AK; EDEN; FRENCKEN, 2007).

The age seems to have a role in children's anxiety. Schricks and van Amerongen (2003) found a significant difference in Venham scores only during the restoration of the cavity where older children showed a lower score. This data is in agreement with the trend found in the current research, where older children were more likely to be satisfied after the two operative procedures. It may occur because the younger subjects feel more tired and less cooperative then the oldest.

Venham, Benston and Cipes (1977) who studied the children's response to sequential dental visitis conclude that dental experience allow the child to more accurately anticipate and respond to specific stressful dental procedure. The present study did not find difference between children with or without dental experience. Once again, this lack of significant difference could be explained by the limited sample size. The vast majority of the children from Lo and Holmegren (2001) and van Bochove and van Amerongen (2006) studies have no prior dental experience.

The only variable that showed a significant difference was the time taken to perform the procedures. Conventional approach took more then 2 times of the ART to be completed. The mean time taken for ART was 16.19 minutes a little longer then 10.5 minutes from the Lo and Holmegren study (LO; HOLMGREN, 2001). But, in general the time taken to provide ART is in accordance to previous studies (FRENCKEN; MAKONI; SITHOLE, 1998; FRENCKEN et al.,1998).

We believed that administration of local anesthesia and the use of bur were essential for the unacceptability of the Conventional approach. In the other hand, collocation of matrix band and wooden wedges were the crucial factor for unacceptability of ART. Additionally, the collocation of those accessories constantly caused crying and bleeding that interfered on the ART restoration performances. Thus, this approach probably would show better results if only occlusal surface was involved.
Further investigation, regarding class II caries lesion should be conducted. Moreover, a specifically instrument to assess dental anxiety in children should be used. Mickenautsch, vant' Hof and Frencken (2007) evaluate the anxiety of 8-10 year-old children using a shortened form of the Children's Fear Survey Schedule - Dental Subscale (CFSS-DF). They found CFSS-DF to be an ideal instrument to use when comparing conventional approach (with local anesthesia and drilling the teeth) with less invasive treatments. The inconvenient factor of this instrument is that young children can not respond by themselves (TEN BERGE et al., 1998).

\section{Conclusion}

In spite of ART approach did not demonstrate to have higher acceptability then the conventional approach, it is important to emphasis that ART presents interesting characteristics when providing dental care to children. The short time taken to complete the procedure, the absence of local anesthesia and rotary instruments seems to be worthy aspects when dealing to very young children or patients with behaviors problems. Therefore investigations should be conducted with lager sample size in order to identify children's treatments preference. Moreover still necessary the development of an ideal instrument to assess acceptability in young children.

\section{References}

BUCHANAN, H.; NIVEN, N. Validation of a facial image scale to assess child dental anxiety. Int. J. Paediatr. Dent., Oxford, v. 12, no. 1, p. 47-52, Jan. 2002.

FRENCKEN, J.E.; MAKONI, F.; SITHOLE, W.D. et al. ART restorations and glass ionomer sealants in Zimbabwe: survival after 3 years. Community Dent. Oral Epidemiol., Copenhagen, v. 26, no. 6, p. 372-381, Dec. 1998

FRENCKEN, J.E. et al. Three-year survival of one-surface ART restorations and glass-ionomer sealants in a school oral health programme in Zimbabwe. Caries Res., Basel, v. 32, no. 2, p. 119126, 1998.

HOLMGREN, C.J.; FRENCKEN, J.E. Painting the future for ART. Community_Dent. Oral Epidemiol., Copenhagen, v. 27, no. 6, p. 449-453, Dec. 1999.

LO, E.C.; HOLMGREN, C.J. Provision of atraumatic restorative treatment (ART) restorations to chinese pre-school children--a 30month evaluation. Int. J. Paediatr. Dent., Oxford, v. 11, no. 1, p. 3-10, Jan. 2001.

LO, E.C.; LUO, Y. et al. Clinical investigation of two glass-ionomer restoratives used with the atraumatic restorative treatment approach in China: two-years results. Caries Res., Basel, v. 35, no. 6, p. 458463, Nov./Dec. 2001.

MICKENAUTSCH, S.; FRENCKEN, J.E.; VANIT, H.M. et al. Atraumatic restorative treatment and dental anxiety in outpatients attending public oral health clinics in South Africa. J. Public Health Dent., Raleigh, N.C., v. 67, no. 3, p. 179-184, Summer 2007.

MICKENAUTSCH, S.; VAN'T HOF, M.A.; FRENCKEN, J.E. Oral health service systems in Gauteng Province, South Africa. East Afr. Med. J., Nairobi, v. 84, no. 4, p. 178-182, Apr. 2007. 
RYGE, G. Clinical criteria. Int. Dent. J., London, v. 30, no. 4, p. 347358, Dec. 1980.

SCHRIKS, M.C.; VAN AMERONGEN, W.E. Atraumatic perspectives of ART: psychological and physiological aspects of treatment with and without rotary instruments. Community Dent. Oral Epidemiol., Copenhagen, v. 31, no. 1, p. 15-20, Feb. 2003.

TEN BERGE, M. et al. The dental subscale of the children's fear survey schedule: a factor analytic study in The Netherlands. Community Dent. Oral Epidemiol., Copenhagen, v. 26, no. 5, p. 340-343, Oct. 1998.

TOPALOGLU-AK, A.; EDEN, E.; FRENCKEN, J.E. Perceived dental anxiety among schoolchildren treated through three caries removal approaches. J. Appl. Oral Sci., Bauru, v. 15, no. 3, p. 235-240, June 2007.

VAN 'T HOF, M.A. et al. The atraumatic restorative treatment (ART) approach for managing dental caries: a meta-analysis. Int. Dent. J., London, v. 56, no. 6, p. 345-351, Dec. 2006.

VAN AMERONGEN, W.E.; RAHIMTOOLA, S. Is ART really atraumatic? Community Dent. Oral Epidemiol., Copenhagen, v. 27, no. 6, p. 431-435, Dec. 1999.

VAN BOCHOVE, J.A.; VAN AMERONGEN, W.E. The influence of restorative treatment approaches and the use of local analgesia, on the children's discomfort. Eur. Arch. Paediatr. Dent., Leeds, England, v. 7 , no. 1 , p. 11-16, Mar. 2006.

VENHAM, L.; BENGSTON, D.; CIPES, M. Children's response to sequential dental visits. J. Dent. Res., Chicago, v. 56, no. 5, p. 454459, May 1977.

Rev. Fac. Odontol. Porto Alegre, v. 53, n. 1, p. 27-31, jan./abr., 2012. 